FACTA UNIVERSITATIS

Series: Physical Education and Sport, Vol. 17, No 3, 2019, pp. 523 - 529

https://doi.org/10.22190/FUPES191024046S

Research article

\title{
THE INFLUENCE OF STRENGTH ON THE RESULTS OF THE VORTEX THROW
}

\author{
UDC 796.433.012
}

\author{
Daniel Stanković, Jelena Šućur, Aleksandar Raković \\ ${ }^{1}$ Faculty of Sport and Physical Education, University of Niš, Niš, Serbia \\ ${ }^{2}$ Athletic club "Kruševac", Kruševac, Serbia
}

\begin{abstract}
The aim of this paper was to determine the influence of strength on the results of the vortex throw. The research was carried out on a sample of 50 children aged 7 to 10, using the following measuring instruments for the evaluation of strength: the standing long jump, throwing a medicine ball from a supine position, torso lifts for $30 \mathrm{~s}$ knees bent, the plank and hanging leg raises. The research also included one measuring instrument for the evaluation of the distance in the vortex throw (the criterion variable). Based on the obtained results, it can be concluded that strength has a statistically significant influence on the results of the vortex throw among children aged 7 to 10 with a shared variability of approximately $43 \%$. The greatest part of this significance can be ascribed to the tests of the medicine ball throw from a supine position which is responsible for the evaluation of the strength of the arms and shoulder belt. There were also significant correlations of the variables the standing long jump and torso lifts for $30 \mathrm{~s}$ knees bent with the result in vortex throw, but they did not significantly affect the results for this age group.
\end{abstract}

Key words: Athletics, Strength, Vortex Throw

\section{INTRODUCTION}

Teaching throws, and training in general, often requires a number of innovative methods to be implemented, a substitute equipment to be used and new elements that improve sports results to be explored (Konieczny \& Iskra, 2013). The vortex has already been approved for the development of the technical expertise of throwing. Based on the dimensions of the javelin, it is clear that for younger age groups it is difficult to overcome the gain control of the implement, and thus difficult to learn the throwing technique. The vortex, whose weight is $135 \mathrm{~g}$, does not require great strength, nor does it allow the possibility for injury to the

Received October 24, 2019/ Accepted December 24, 2019

Corresponding author: Daniel Stanković

Faculty of Sport and Physical Education, University of Niš, Čarnojevića 10a, 18000 Niš, Serbia

Phone: + 38118510900 •E-mail: extremeds@gmail.com 
soft tissue of the shoulder belt and elbow. Its length of $34 \mathrm{~cm}$ enables easy handling, while its shape allows it to be held in the same way that the javelin is held. This makes it an ideal substitution implement as it creates another link between these two throwing props. The way in which this implement is thrown is identical to the way the javelin is thrown. Thus, the throwing technique of the vortex is completely the same as the throwing technique for the javelin and consists of the following phases: the approach, the carry, the withdrawal, the transition, the pre-delivery stride, delivery, and recovery (Tešanović, 2009; Tešanović \& Bošnjak, 2009). In addition to learning about the throwing technique (Konieczny \& Iskra, 2013), this implement is also an excellent prop for numerous games (Antekolović, Ajman, \& Ljubičić, 2018), while the high level of connection between the variables which describe success in throwing a ball and throwing a vortex will later lead to a positive transfer of the throwing technique to the javelin (Puklavec, 2010).

Motor skills and their influence on the results on the javelin throw, which is in terms of technique very close to the vortex throw, have been studied by numerous authors (Ivanović, 2009; Morris \& Bartlett, 1996; Branković, Bubanj, \& Janković, 1995; Milanović, Hofman, Puhanić, \& Šnajder, 1986; Milanović, 1980; Milanović, 1976). These studies point out the motor skills of javelin throwers which separate them from the rest of the population. Thus Milanovic (1976) in his paper reached the conclusion that the results of the javelin throw are affected by absolute and relative strength. Branković et al. (1996) provide an evaluation of the importance of each characteristic individually (from -5 to +5 ) so that we obtain a model in which the speed of alternative movements, explosive strength and flexibility were rated with +5 , coordination, precision and general strength with +4 , and finally balance and maximal force of the attempted movements with +3 . Morris \& Bartlett (1996) in their paper reached the conclusion that for a javelin thrower, speed is most important, including speed of release, since among elite throwers the javelin develops $70 \%$ of its speed during the final 0,1 seconds of release. Ivanovic (2009) supports these findings with the conclusion that throwing a javelin high is conditioned by the motor abilities of the thrower with a shared variance of $37 \%$. The greatest effect on the javelin throw was achieved by the tests for the evaluation of speed, explosive strength, balance and finally repetitive strength.

There is a lack of studies which dealt with the problems of the influence of motor abilities, including strength, on the results of the vortex throw. Aleksovska \& Pop-Petrovski (2012), working with a sample of 70 thirteen-year-olds, determined that the applied anthropometric (9 tests) and motor (11 tests) variables has a significant influence on the results of the vortex throw. The research of Pavić, Ljubičić, Zagorac, Čavala, \& Jukić (2016) was carried out with the aim of determining the extent of the connection between morphological and motor characteristics and success in certain athletic disciplines (the high jump, ball throw, vortex throw). 23 measuring instruments (13 morphological and 10 motor) were applied on a sample of 35 female participants, all fifth-grade elementary school students. The motor variables which had proven to be more significant for the vortex throw include: the standing long jump, the $20 \mathrm{~m}$ sprint, the Edgren side step, Figure eight duck, and the obstacle course backwards. The standing long jump variable and the $20 \mathrm{~m}$ sprint represent tests of explosive strength which have a positive correlation with the vortex throw. The variables of the Edgren side step and the Figure eight duck represent tests of agility which are especially important for the increasingly rapid alternation of steps, especially during the last step before the implement is thrown. The obstacle course backwards represents a test of coordination which has proven to be the most significant variable for success in achieving good results due to the proper harmony between the movement of the arms and legs. 
The aim of this paper is to determine the influence of strength on the results of the vortex throw in children.

\section{METHODS}

\section{The sample of participants}

The research was carried out on a sample of 50 children aged 7 to 10 , from the city of Kruševac. The participants were all members of the athletics school section of the A.C. "Kruševac". At the moment of testing all of the participants were healthy and had parental consent for taking part in the testing.

\section{Measuring instruments}

The research included the following measuring instruments for the evaluation of strength (predictor variables): the standing long jump - SLJ in cm (Metikoš et al., 1989, 74); throwing a medicine ball from a supine position - TMBSP in cm (Metikoš et al., 1989, 71); torso lifts for $30 \mathrm{~s}$, knees bent - TL30 in number of repetitions (Mitrović, 2016, 48); the pushups - PUSHUP30 in number of repetitions; and hanging leg raises - HLR in s (Mitrović, 2016, 49).

The research also included one measuring instrument for the evaluation of the distance in the vortex throw (the criterion variable) - the shot distance for the vortex throw - VORTEX in $\mathrm{cm}$.

\section{Statistical Analysis}

The statistical methods of analyses included the following.

The descriptive statistics comprised: the number of participants $(\mathrm{N})$, mean value (Mean), standard deviation (SD), minimum (Min) and maximum (Max) value of the numerical results, range (Range) and standard error of the mean value (Error). The discriminative measurements were performed by Skewness (Skew) representing the symmetry of substance layout around the arithmetic mean and Kurtosis (Kurt) representing peakedness or flatness of distribution.

To determine the influence of the predicting variables (anthropometric parameters) on the criterion variable (result in lead climbing), a regression analysis was used. It contains the following parameters: coefficient of correlation (r), coefficient of the partial correlation (Part-r), standardized regression coefficient (Beta), vector of the standardized regression coefficient $(\mathrm{t})$, significance of the beta coefficient ( $\mathrm{p}$-level), coefficient of the multiple correlations (R) coefficient of the determination (R2), and the level of the significance of the regression connection on the multivariate level (p).

Data were processed and mistreated by means of the Statistica 10.0 software package. Statistical significance was set at the level of $\mathrm{p}<.05$. 


\section{RESULTS}

Table 1 Descriptive statistics

\begin{tabular}{llrrrrrrrr}
\hline Variables & $\mathrm{N}$ & \multicolumn{1}{c}{ Mean } & \multicolumn{1}{c}{ Min } & \multicolumn{1}{c}{ Max } & \multicolumn{1}{c}{ Range } & \multicolumn{1}{c}{ SD } & Error & Skew & Kurt \\
\hline SLJ $(\mathrm{cm})$ & 50 & 150.56 & 110.00 & 192.00 & 82.00 & 18.73 & 2.649 & .044 & -.552 \\
TMBSP $(\mathrm{cm})$ & 50 & 238.70 & 108.00 & 416.00 & 308.00 & 75.42 & 10.665 & .808 & .153 \\
TL30 (reps) & 50 & 17.08 & 4.00 & 27.00 & 23.00 & 4.12 & .583 & -.142 & 1.496 \\
PUSHUP30 (reps) & 50 & 15.24 & 6.00 & 25.00 & 19.00 & 4.81 & .679 & .227 & -.753 \\
HLR $(\mathrm{s})$ & 50 & 8.47 & 2.00 & 34.70 & 32.70 & 6.92 & .978 & 1.904 & 4.167 \\
VORTEX $(\mathrm{cm})$ & 50 & 1794.34 & 890.00 & 3627.00 & 2737.00 & 677.67 & 95.837 & .648 & -.314 \\
\hline
\end{tabular}

Table 1 shows the results of the basic central and dispersion parameters for the predictor (strength test) and criterion variable (vortex throw). The analysis indicates the good discriminant application of the tests, since within the Range there are always approximately 3-5 standard deviations (SD) of the appropriate variable.

The skewness determines the values of the symmetric distribution, and based on the obtained results it can be concluded that what is mostly found is a normal symmetric distribution for the variables SLJ, TMBSP, PUSHUP30, VORTEX, whose value of distribution ranges from 0 to \pm 1 . What was also determined was a mild asymmetry which is within the normal range only for the variable HLR, where there is a curvature of the distribution to the right, and which indicates a greater number of weaker results compared to the arithmetic means. We can conclude that the value of the distribution which evaluates skewness is satisfactory. Kurtosis determines the value of the homogeneity of the distribution of the data on the basis of the obtained results. Considering that the statistical package calculates the normalization of the kurtosis from 2.75 to 0 , we can conclude that the compactness of the distribution of the data is normal (mesokurtic) for all the variables, except for the variable HLR where we find a strong platykurtic data distribution.

Table 2 Intercorrelation matrix

\begin{tabular}{lrrrrrr}
\hline Variables & SLJ & TMBSP & TL30 & PUSHUP30 & HLR & VORTEX \\
\hline SLJ & 1.00 & & & & & \\
TMBSP & $\mathbf{. 6 7}$ & 1.00 & & & & \\
TL30 & $\mathbf{. 5 5}$ & $\mathbf{. 5 1}$ & 1.00 & & & \\
PUSHUP30 & -.02 & .04 & .01 & 1.00 & & \\
HLR & .26 & .04 & .13 & -.04 & 1.00 & \\
VORTEX & $\mathbf{. 4 4}$ & $\mathbf{. 6 0}$ & $\mathbf{. 3 5}$ & .14 & .24 & 1.00 \\
\hline \multicolumn{7}{l}{ Legend: The marked correlations are significant at level $\mathrm{p}<.05$} \\
\end{tabular}

Table 2 shows the intercorrelations between the predictor (strength tests) and criterion variables (the vortex throw). A strong connection was noted for the variable of the TMBSP and the SLJ (.67), as well as for the VORTEX (.60) and TL30 (.51). In addition, a statistically significant connection was determined between the variables of the SLJ and TL30 (.55), as well as the variable VORTEX and the variable SLJ (.44) and TL30 (.35). The remaining correlation coefficients were not statistically significant. 
Table 3 Regression analysis

\begin{tabular}{lcccccc}
\hline Variables & $\mathrm{r}$ & Part-r & \multicolumn{1}{c}{$\mathrm{b}$} & Std.Err. of b & $\mathrm{t}(23)$ & $\mathrm{p}$-value \\
\hline SLJ & $\mathbf{4 4}$ & -.037 & -1.53 & 6.14 & -.2483 & .8050 \\
TMBSP & $\mathbf{. 6 0}$ & $\mathbf{. 4 9 0}$ & $\mathbf{5 . 4 1}$ & $\mathbf{1 . 4 5}$ & $\mathbf{3 . 7 2 7 7}$ & $\mathbf{. 0 0 0 5}$ \\
TL30 & $\mathbf{. 3 5}$ & .033 & 5.08 & 23.03 & .2205 & .8265 \\
PUSHUP30 & .14 & .164 & 17.77 & 16.10 & 1.1039 & .2756 \\
HLR & .24 & .279 & 22.75 & 11.79 & 1.9291 & .0602 \\
\hline \multicolumn{1}{c}{ R=.6560 } & & $\mathrm{R}^{2}=.4304$ & & $\mathrm{~F}(5.44)=6.6483$ & $\mathrm{p}<.00011$ \\
\hline
\end{tabular}

By analyzing the data in Table 3 which shows the influence of strength on the vortex throw, we can note a statistically significant influence on the multivariate level $(\mathrm{p}<.00011)$. What speaks in favor of this is the high multiple correlation coefficient $(\mathrm{R}=.6560)$, as well as the determinant coefficient $\left(\mathrm{R}^{2}=.4304\right)$ which indicates approximately $43 \%$ of the total connection between the system of predictor variables (tests of strength) and the criterion.

The analysis of the influence of individual predictor variables on the criterion can be noted only for the variable of the medicine ball throw from a supine position TMBSP, which has a statistically significant influence on the vortex throw $(p<.0005)$. For the remaining variables, a statistically significant influence was not determined, even though the HLR was close to the level of significance.

\section{DISCUSSION}

The obtained results indicate that the studied predictor and criterion variables are in a certain correlation. Namely, it can be noted that there is a high connection between the variable of the medicine ball throw from a supine position and the vortex throw (.60), as well as the standing long jump variable (.44) and torso lifts in $30 \mathrm{~s} \mathrm{(.35).}$

A statistically significant influence of the set of variables for the evaluation of strength on the results of the vortex throw were determined with approximately $43 \%$ of the total connection between the system of predictor variables (tests of strength) and the criterion. These results support the existing body of research (Pavić et al., 2016; Aleksovska \& PopPetrovski, 2012; Žuvela, Borović, \& Foretć, 2011; Bourdin et al., 2010; Ivanović, 2009; Bouhlel, Chelly, Tabka, \& Shephard, 2007; Harasin \& Milanović, 2003; Branković et al., 1995; Milanović, 1976) in which the influence of strength on the results of the vortex throw was determined.

However, by analyzing individual regression coefficients, that is, the influence of individual predictor variables on the results of the vortex throw, it can be noted that only the variable of the medicine ball throw from a supine position had a statistically significant influence on the result for the vortex throw $(\mathrm{p}<.0005)$. This is in agreement with research which has determined the influence of the strength of the arms and shoulder belt on the results of the javelin throw and vortex throw (Bourdin et al., 2010; Bouhlel et al., 2007), but not with the research in which the influence of explosive strength of the legs was determined, which is necessary for the rapid generation of the large amount of energy needed to perform a throw (Pavić et al., 2016; Žuvela et al., 2011; Tešanović, 2009; Bošnjak, 2006; Harasin \& Milanović, 2003). These findings can be explained by the sample of participants who were included in this research, who were 
far younger than the ones who took part in the cited studies, and which probably led to an insufficiently acquired technique of the vortex throw. The children simply were not able to make use of their run-up potential and the explosive strength of their legs.

\section{CONCLUSION}

Based on the results obtained, it can be concluded that strength has a statistically significant influence on the results of the vortex throw among children aged 7 to 10 with a shared variability of approximately $43 \%$. The greatest part of this significance can be ascribed to the tests of the medicine ball throw from a supine position which is responsible for the evaluation of the strength of the arms and shoulder belt. There were also significant correlations of the variables standing long jump and torso lifts for $30 \mathrm{~s}$ knees bent with the result in vortex throw, but they did not significantly affect the result at this age.

\section{REFERENCES}

Aleksovska, L.P., \& Pop-Petrovski, V.C. (2012). Influence of some motoric and anthropometric variables on the result in throwing vortex at 13 year old students. Research in Kinesiology, 40(1), 43-46.

Antekolović, J., Ajman, H., \& Ljubičić, S. (2018). Application of vortex in elementary sports school during the program Weekends in sport halls. In V. Findak (Ed.). Proceedings Book 27th Summer School of Kinesiologists of Republic of Croatia, (pp. 153-158). Zagreb

Bošnjak, G. (2006). Relacije antropoloških obeležja sa rezultatskom efikasnošću u bacanju koplja kod srednjoškolske omladine (Relations of anthropological features with resultant efficiency in throwing spears in high school youth). PhD Thesis, Novi Sad: Faculty of Physical Culture. In Serbian

Bouhlel, E., Chelly, M S., Tabka, Z., \& Shephard, R. (2007). Relationships between maximal anaerobic power of the arms and legs and javelin performance. Journal of Sports Medicine and Physical Fitness, 47(2), 141-146.

Bourdin, M., Rambaud, O. Dorel, S., Lacour, J.R., Moyen, B., \& Rahmani, A. (2010). Throwing performance is associated with muscular power. International Journal of Sports Medicine, 31(7), 505-510.

Branković, M., Bubanj, R., \& Janković, M. (1995). Struktura vodećih elemenata antropoloških karakteristika atletičara (The structure of the leading elements of the anthropological characteristics of athletes). Apollinem Medicum et Aesculapium, 90-91. In Serbian

Harasin, D., \& Milanović, D. (2003). Bacanje kao oblik gibanja u kondicijskoj pripremi sportaša (Throwing as a form of motion in the fitness preparation of athletes). In: D.Milanović, \&. Jukić (Eds.), Proceedings of the Scientific-Professional Conference "Conditioning of Athletes", (pp. 175-179), Zagreb: Faculty of Physical Culture, University of Zagreb. In Croatian

Ivanović, M. (2009). Relations between motor abilities and javelin throw results of adolescents. Sport Science, 2 (1), 84-90.

Konieczny M., \& Iskra J. (2013). Result determinants in children's and teenagers' fly-throws in terms of dynamic asymmetry. Antropomotoryka, 23(64), 71-79.

Metikoš, D., Prot, F., Hofman, E., Pintar, Ž., Oreb, G., Agrež, F., et al. (1989). Mjerenje bazičnih motoričkih dimenzija sportaša (Measuring the basic motor dimensions of athletes). Zagreb: Faculty of Physical Culture, University of Zagreb. In Croatian

Milanović, D. (1976). Relacije između manifestnih i latentnih dimenzija dizanja utega i rezultata u bacanju kugle, diska i koplja (Relations between manifest and latent dimensions of weightlifting and results in throwing a ball, disc and javelin throw). Kineziologija, 6 (1-2), 193-204. In Croatian

Milanović, D. (1980). Kanonička povezanost morfoloških i motoričkih karakteristika i rezultata u nekim atletskim disciplinama (Canonical correlation of morphological and motor characteristics and results in some athletic disciplines). Kineziologija, 10, 26-32. In Croatian

Milanović, D., Hofman, E., Puhanić, V., \& Šnajder, V. (1986). Atletika, znanstvene osnove (Athletics, scientific fundamentals). Zagreb: Faculty of Physical Culture, University of Zagreb. In Croatian 
Mitrović, N. (2016). Effects of programmed Taekwondo exercise on some anthropological characteristics of young students. PhD Thesis, Novi Sad: Faculty of Sport and Physical Education, University of Novi Sad. In Serbian

Morriss, C., \& Bartlett, R. (1996). Biomechanical factors critical for performance in the men's javelin throw. Sports Medicine, 21(6), 438-446.

Pavić, D., Ljubičić, H., Zagorac, N., Čavala, M., \& Jukić, J. (2016). Uticaj nekih motoričkih sposobnosti i morfoloških karakteristika na rezultat u bacačkim i skakačkim disciplinama kod ispitanica kadetskog uzrasta. In: G., Kasum (Ed.), Proceedings of the International Scientific Conference "Effects of physical activity application to anthropological status with children, adolescents, and adults" (pp. 108-112). Belgrade: Faculty of Sport and Physical Education of the University of Belgrade.

Puklavec, A. (2010). Povezanost rezultata bacanja loptice i bacanja vrtloga (Relationship between ball throwing and swirling throwing). In V. Findak (Ed.). Proceedings Book 19th Summer School of Kinesiologists of Republic of Croatia, (pp. 288-294). Zagreb

Tešanović, G. (2009). Relacije nekih antropomotoričkih sposobnosti sa postignutim rezultatom u bacanju vorteksa (Relations of some anthropomotor abilities with the result in vortex throwing). Unpublished Master Thesis, Banjaluka: Faculty of Physical Education and Sports. In Serbian

Tešanović, G., \& Bošnjak, G. (2009). Primjena vortexa kao zamjenskog rekvizita u trenažnom procesu mladih bacača koplja (The use of vortex as a replacement props in the training process of young javelin throwers). Sportekspert, 2(2), 18-21. In Serbian

Žuvela, F., Borović, S., \& Foretć, N. (2011). The correlation of motor abilities and javelin throwing results depends on the throwing technique. Facta Universitatis Series Physical Education and Sport, 9(3), 219-227.

\section{UTICAJ SNAGE NA REZULTAT U BACANJU VORTEKSA}

Cilj ovog rada bio je utvrđivanje uticaja snage na rezultat u bacanju vorteksa. Istraživanje je sprovedeno na uzorku od 50-oro dece starosti od 7 do 10 godina, pomoću sledećih mernih instrumanta za procenu snage: skok u dalj iz mesta, bacanje medicinke iz ležanja na leđima, podizanje trupa iz ležanja pogrčenim nogama, upor ležeći za rukama i izdržaj u visu zgibom. U istraživanju je korišćen jedan merni instrumenti za procenu daljine u bacanju vorteksa (kriterijumska varijabla). Na osnovu dobijenih rezultata može se zaključiti da postoji statistički uticaj snage na rezultat u bacanju vorteksa kod dece uzrasta 7 do 10 godina sa zajedničkim varijabilitetom od oko 43\%. Najveći udeo te značajnosti može se pripisati testu bacanje medicinke iz ležanja na leđima koji je odgovoran za procenu snage ruku i ramenog pojasa. Postoje $i$ značajne korelacije varijabli skok udalj iz mesta $i$ podizanje trupa iz ležanja pogrčenim nogama sa rezultatom u bacanju vorteksa, ali one nisu značajno uticale na rezultat $u$ ovom uzrastu.

Ključne reči: atletika, snaga, bacanje vorteksa 